\title{
The Residue of Anthropocentrism in Heidegger's Question after Technic
}

\section{Heideggerin Tekniğe İlișkin Sorgulamasındaki İnsan-merkezcilik Kalıntısı}

\begin{abstract}
In his text, The 2uestion Concerning Technology, Heidegger argues that modern mind is unaware of Being's self-destining which determines Dasein's relation to their own essence and that of other beings because it is in a delusion of being an 'efficient cause'. A bluntness of this kind not only endangers human-freedom but also puts natural entities at the risk of losing their authenticity since the modern mode of production regards nature as a reserve that is constantly in the service of human-doings. Accordingly, the discussion carried out in this article is, despite his criticism of the conception of 'agency' underlying western metaphysics, whether or not Heidegger overcomes the problem of anthropocentrism in his own philosophy.
\end{abstract}

Keywords: Heidegger, anthropocentrism, nature, Dasein, technology, technic, art.

(C) Akkın, İ. O. (2018). The Residue of Anthropocentrism in Heidegger's Question after Technic. Beytulhikme An International fournal of Philosophy, 8 (2), 427-440. 


\section{Introduction}

Heidegger (1962)'s text “die Frage nach der Technik" is built upon a series of phenomenological questions unfolding, gradually, through a meditation on technology and the relation that human being, Dasein, has to it. Right at the beginning of his article, Heidegger asserts that his intention is to seek for a way through which a free relationship between human being and technology can be established. Therefore, although the question concerns technology, it is deeply a question about Being (Heidegger, I993: 328). Human being is not only one side of the coin in Heidegger's investigation, but also the primary correspondent of the danger and the saving power he sees in the essence of technology which comes out of Being itself.

Heidegger argues that Being does not send the same destiny, Geschick, for itself throughout the history. At one stage, specifically, in Antiquity, it destined itself as eidos, 'the being of being', and, in other epochs, the names of the destiny were reason, spirit, will to will etc. In the pre-Socratic period, it was poiesis and, at present, the last name Being sends is for its destiny is "Gestell" (Brogan, 2007: 49). Therefore, Heidegger takes the position that the essence of modern technology, Gestell, is not a human doing; on the contrary, it is the way in which Being gives itself, that is, by concealing itself in and as the complete unconcealed-ness of beings. Nevertheless, Being happens between beings, entities, and Dasein; i.e., there is a reciprocal relation between them. In this respect, although Heidegger does not admit that humans are autochthonous beings, there is still a residue of anthropocentrism in his philosophy according to which it is meaningless to think of the aletheic movement of physis without Dasein.

The way Heidegger transforms Greek terms and constructs new concepts can be regarded as a remedy of the human-centred attitude too since these terms are given an anthropomorphic character so that Dasein attains the momentous role of being the correspondent of beings. Ironically, when Heidegger is most cautious about not to think of natural events as human-doings, his terms become the most anthropomorphized. For instance, he thinks that the originary parting of being into different "regional ontologies" as physis, that is, into 'the natural' and 'the artificial', 
is not a human-doing but it "belongs to physis" (Brogan, 2007: 44). Nonetheless, he describes this event as a "de-cision," "Ent-scheidung", according to which physis is regarded as generating the physei-ousia, growing things, on the one hand, and byle, matter and morphe, form, on the other (44). The role of Dasein is, thusly, placed within the 'decision' of physis while it seems as if there is no praise to the fact that humans happen to exist. Seemingly, this reversed anthropocentrism; i.e., taking it as if it is nature who offers itself to human beings', lessens the impact of Dasein, and it becomes as if nature approves its own destruction. Furthermore, Heidegger expressly states that his real concern is not the destruction that nature is exposed to-e.g., the genetically modified foods, hydroelectric stations, cloned DNAs, nuclear energy and lab animals are not his problems. For him, it is the way of thinking and the danger concealed in the way Being essences itself: Gestell is the danger which, above all, endangers the essence of Dasein. This is a proof of the unaimed humanism in Heidegger's philosophy, and in order to present a well-developed argument to support this claim, the phenomenological order Heidegger establishes in "the Question Concerning Technology" needs to be followed. Accordingly, it is initial to concentrate on Heidegger's phenomenological method and, secondly, the contrast he sees between ancient and modern modes of producing-poiesis vs. Gestell-must be examined and, finally, the belief in the danger and the saving power can be interpreted as the safe shore of humanism remaining in Heidegger's question after technology.

\section{Heidegger's Way}

According to Heidegger (1993), when we judge technology by its usefulness/harmfulness-with no reference to its essence-what we have in mind is, indeed, 'technological devices', and this is an example of the instrumentalist mode of explanation through which we are set aside from the actual thing in question. This is because the doxic layers which cover the essence of technology cannot be cleaned up by the instrumentalist or anthropocentric conceptions (3I2). With the definition of a 'doxic conception', Heidegger already introduces the type of bumanism he is opposed to, that is, "man is the measure of everything", and we are thusly precluded from judging him as a humanist. Nonetheless, as it will be dis- 
cussed further, he is still an 'anthropocentric' philosopher in at least one sense of the term.

For Heidegger (I993), the logic of the excluded middle, the either/or thinking, is a typical example of the doxic conception (3II). Regarding technology, the alternative he proposes against the excluded middle is neither simply pointing out technology's goodness/badness nor rejecting that it is either good or bad, the neutral stance, or taking no notice of it (312). Hence, in questioning technology, his task is to show this phenomenon from within-to show itself as it is in its essence. To illuminate the distinction between essences and instances, we might consider the example of a tree. The 'tree', as a concept, is different from particular trees out there: "If we want to know the 'tree' as such, [its essence, the tree-ness itself,] we wouldn't look for it among trees . . . [Similarly,] the essence of technology is 'by no means' anything technological” (3II, 334).

Heidegger (I993)'s aim in making a distinction between technology and its essence is to establish an open, free, relationship between Dasein and technology as well as deconstructing the "history" of productionist metaphysics and preparing a "way" for the arrival of a new epoch in the history of Being (329; Zimmerman, 1990: 222). However, it should be underlined that he does not deconstruct metaphysics itself or inscribe a new metaphysical system. In the age of modern technology, history of Being has the name Ge-stell, according to which the productionist understanding is widely-imposed. Therefore, Heidegger believed that "in meditating on the nature of Gestell" he could gain an "insight into the new beginning"; i.e., sense the saving power in technology.

Having stated that the 'essence' of technology is different from the technological devices, Heidegger tries to put forth his second thesis that this essence has not been the same for all the time. With the Socratic intervention, there has been a crucial break with the cosmologists (Parmenides, Thales, Heraclitus...). As Cicero (I886) puts it, it was Socrates who "first called philosophy down from heaven, and [...] forced it to make inquiry into life and morals [...]" (257). Put differently, with the Socratic intervention, the focus of philosophy has changed as it has become a matter of the city instead of being concerned with the cosmos. Therefore, Heidegger advocates the view that the essence of modern technolo- 
gy was already prepared with the Socratic shift of perspective, which will be explained in the following section.

\section{Ancient Conception of Technology}

According to the modern understanding, "Truth" is an achievement of humans whereas for Parmenides it was a Goddess that of which we do not have control (Zimmerman, I990: 175). In most of his works, Heidegger empathises with the pre-Socratic theory of truth and states that Truth is disclosed to human beings; i.e., we are receivers, not agents of truth. Dasein is the open site where the disclosure of being happens. However, in western metaphysics, starting from the Socratic shift, humans have been regarded as the one in control. The notion of mastery and control also shows itself in the modern conception of 'causality' which did not exist in the pre-Socratic period.

To understand the essence of ancient technology, Heidegger (I993) focusses on particular things like the chalice example (315). The Romans adopted the paradigm of "four-causes" which is rather close to the modern conception of causality. According to this view, making of a chalice consists of four stages in each a certain type of causa is dominant. The materia is the causa materialis and it is the first underlying cause. The second is causa formalis, and the third is causa finalis, the end in view. The last one is causa efficiens, the person who makes the chalice; i.e., who is efficient in the completion of the making of the chalice (313-3I4). Modern understanding of causality consists of four phases as well: matter, form, end/purpose and the efficient cause-the silversmith, agent, who makes the chalice. It should be noted that, both in Roman and modern versions of it, the silversmith is considered as the most active and dominant cause whereas matter is regarded as passive raw material, standing reserve, on which the form is imposed. On the contrary, Ancient Greeks considered each of the four aitiai (namely, byle, eidos, telos and technities) as equally 'coresponsible' for the producing of the chalice. Therefore, the chalice is obliged, "indebted", to the aitiai (Heidegger, I993: 314). To clarify, Greeks regarded byle and other parts of the aitiai as co-operating in order to produce the chalice, which was a guided, not arbitrary, cooperation. It is as if byle itself suggests an eidos, a telos and a technities to produce the chalice. 
The silver does not impose it, but only suggests it. "This is like making little statues out of some clay; i.e., that lamp of clay is sort of pregnant to the other three aitiai" (315; Brogan, 2007: 51).

In the Greek case, the artisan is not a technities without the suggestions of the byle. Hence, the chalice is not exclusively indebted to one but to all four aitiai. "An aition is something that lets something come into its own" (Heidegger, 1993: 315). According to 'the modern cause'; however, someone brings something, which was previously non-existent, into existence through an act of 'wilful force', and this wilful force is an active subject, whereas the aitiai are passive, indebted. In the producing of the chalice, the co-responsible fourth thing is the Silversmith but not in the manner of causa efficiens (Heidegger, I993: 315). What the Silversmith does is only a "careful consideration and gathering together", legein, of the other three aitiai (315).

It is crucial to understand Heidegger's interpretation of the Greek way of producing in terms of aletheia; i.e., as a movement from unconcealment to concealment. While producing in the sense of self-showing,

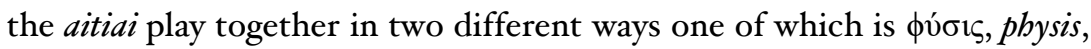
and the other is $\tau \dot{\varepsilon} \chi \nu \eta$, techne. Whereas in techne self-showing happens through the intervention of another, the technities, in physis it is like a selfhappening, an eruption, like bursting out of a blossom (Heidegger, I993: 317). The technities 'occasions', releases, the thing to begin self-showing. In techne, it is a prerequisite that the thing is lying before and lying ready, "Vorliegen und Bereitliegen", for the movement from concealment to unconcealment to happen (316; Heidegger, I962: 10). The aletheic movement, qualitative change, can happen only under appropriate conditions, that is to say, when the right conditions come together the thing can be let come to its own'. Both techne and physis are modes of bringing forth, poiesis. Techne is an active letting, "Ver-an-lassen", but the un-concealing itself is not a human doing in the modern sense (Iо). Humans can only feel "responsible" for revealing, "Entbergen", the process of unconcealment since the thing itself has to be in this process beforehand (II; I993: 318).

Heidegger (1962) suggests that physis has an intrinsic tendency towards self-actualization; therefore, being can break open or erupt, "aufbrucb", through physis (II). Physis (eruption in itself) is poiesis in the highest 
sense because it is a self-happening through which the thing is smoothly actualized. Therefore, things in accordance with physis are ontologically self-sufficient, but things that are produced by techne are deficient in that they need the human element, the technities. In this respect, artefacts are beings by techne and growing things are beings by physis (1998: 192).

In the case of poiesis through techne, the human response to the aletheic movement is Entbergen, revealing. The doing of the technities is a proper activity of legeein, seeing beforehand. It is, in a certain sense, close to theoria, carefully considering or episteme. The technities finds a proper way of gathering together the aitiai. With this activity, something that would not occur otherwise is uncovered through revealing. This is not creation ex nibilo, but, like discovering something which is already there; i.e., responsiveness to the potential through each of the aitiai. In this context, the movement of Being is prior to the human response and; thus, it is ontologically primordial. Nevertheless, neither legein nor the function of techne, episteme or logos should be regarded in the sense of a dominant, active, making. In the Greek model, we are expected to understand byle and morphe as active participants of the poetic mode of producing. When Being essences itself like this, human beings are not the masters but only correspondents of physis. Though, it should be noted that Heidegger does not concentrate much on the self-disclosure of physis as physei-ousia (growing things) but more on the artificial aspect of self-disclosure. This is because the artificial is the only area where human being can establish a relation with Being and; thus, find an opportunity of self-actualizationessence(ing) oneself as a free being whose being is there among other beings. Therefore, it can be said that even in his reading of the Ancient Greek mode of producing or technology, Heidegger's real concern is neither technology nor physis or nature, but the way human being could establish a freer relation with Being in the mode of poiesis. For the same reason, Heidegger's contrastive investigation of poiesis and Gestell, mostly, matters to Dasein.

\section{Modern Conception of Technology}

In his reading of the Greek conceptions of physis and techne, Heidegger claims that these notions were mirror images, and the Greek- 
poiesis was a more originary mode of producing than modern technology.

As Zimmerman (1990) explains, the pre-Socratics were aware of the ontological difference between Being and entities because "they experienced the being of entities as presencing, as rising into appearance, as unconcealment" (223). Therefore, Heidegger interprets Parmenides' phrase, "being and thinking are the same", to mean that "there is an internal relationship between the temporal transcendence of human existence" and "the presencing of entities" (223-224). However, starting from Plato's conception of eidos, there has been an "obscuration" in the relation between Being and beings: Plato's ideas resulted in the reduction of Being itself to the status of a superior kind of entity (224). In the $19^{\text {th }}$ century; however, while for something "to be" meant extensionality, matter, energy, sensibleness and calculability, "Being" itself came to mean nothing apart from entities (Heidegger, I996: 83-94). Cartesian construction of being (substance ontology) contemplates "nature" simply as calculable materia (Ruin, 2010: I85-186). Substantialist metaphysics understands being in terms of presence-at-hand, Vorbandenbeit. On the contrary, for the Greeks, the mode of being for things, pragmata, with which we are concerned in praxis is Zubandenbeit, readiness-to-hand. Pragmata is not meaningless spatial extension, but always contextually meaningful things embedded in a whole surrounding world of concerns. Therefore, pragmata are not "objectified" but they live within a pre-reflective referential context. In this sense, Heidegger's analysis of the "world" departures from pragmata. The primary phenomenon of world, "lived world", is a meaning-context into which we are always already thrown, whereas the other is an objectified world of calculable entities as presented in natural science (Ruin, 2010: I86).

In the transition from the pre-Socratic pragmata to the Platonic and modern conceptions of Vorbandenbeit, the "original forgetfulness" occurred (Ruin, 20IO: I86). It is forgotten that there is a mutual belonging between Being and human beings and Being is approached in a manner of Bestand.

Bestand and Gegenstand are defined in contrast. Whatever is in the manner of Gegenstand is standing opposite or against. Gegenstand is authentic in the sense that its relation to something outside is not ruined 
but, at the same time, it can stand on its own. It has a relative autonomy, stability and permanence. On the contrary, Bestand has been forced to show itself in a way that abolishes its independent aspect, eradicate its autonomous aspect. Therefore, it is completely disposable. Bestand is completely without reserve and subordinated to human demands.

In the technological era, to be means to be an object in nature and nature reveals itself mainly as commodity. In other words, according to modern technology, the mode of being for everything is Bestand, standing reserve. Therefore, the essence of modern technology, Gestell, is "the challenging claim that gathers human beings with a view to ordering [bestellen] the self-revealing [Gegenstand] as standing reserve [Bestand]" (Heidegger, I993, as cited in, Ruin, 2010: I83).

In Gestell, entities are pushed beyond their own intrinsic limits. Regarding the notion of intrinsic possibilities of living things, examples of laboratory animals and human foetuses can be considered since these are mistreated or disclosed inappropriately by the technological understanding. In this sense, Heidegger sees the technological world as an un-world as this way of disclosing things lacks the insight into the intrinsic possibilities or limits of things which makes the world a genuine historical world (Zimmerman, I990: 227).

Heidegger criticizes the $2 \mathrm{O}^{\text {th }}$ century claims that "absolute truth is attainable" through reason and "science is the only valid methodology for attaining that truth" for the bubris underlying these generalizations. They miss the point that "the hidden law of the earth" is an impenetrable mystery (Zimmerman, I990: 227). According to his view, "science was genuine only if it succeeded in taking the measure from things, instead of imposing a measure upon them" and the "finitude of human existence" should refrain us from efforts to gain an "absolute" or total understanding of things (228).

Nevertheless, in Heidegger's philosophy, Being as "presencing through/in another" prevails over "self-emergence of entities in themselves" because Being of entities in the sense of artefacts is a phenomenal event dependent upon the existence of humans (Zimmerman, I990: 225). This is because self-manifesting "requires a clearing or an absencing ... constituted by" Dasein (225). Heidegger "defines the openness of Dasein as 
being 'appropriated' (ereignet) as the site through which presencing occurs" (226). In other words, it is not the case that the being of an entity is really nothing more than its appearing; entities "give themselves" to us; they are discovered, not "projected" or "invented" by us (226). In this reading, humans are given quite an important role in their interrelation to Being. Heidegger never emphasizes this role from the perspective of modern subjectivity or Platonic anthropocentrism but, still, he describes Being in a way that encapsulates human being as an indispensable actor of the self-disclosing event of Being. Therefore, it is evident that Heidegger's philosophy can be regarded as a peculiar kind of humanism.

\section{The Danger}

By shedding light on the notions of 'destiny', 'history', 'freedom' and 'danger', we might gain an insight into Heidegger's view of humanism and make it clearer how he relates the essence of modern technology to the essence of human being, that is, freedom in a certain sense.

First of all, Heidegger indicates that, in modern technological era, the way everything is revealed as standing reserve is neither completely a human doing nor totally isolated from the human realm (Heidegger, 1993: 329): There is an interplay of Being and Dasein: The essence of human being - freedom to place itself in relation to the self-showing of Being; and thus, being the site through which Being can come to its own; i.e., giving an ear or showing a response to the aletheic movement of physis-is quite a necessary element for Being to show itself, for the completeness of the physis. In Gestell; however, humans regard themselves as masters, while everything else become objects of their making. Nevertheless, there is a point where humans cannot be differentiated from other beings or secure their essence as a free being because, in Gestell, human being is also regarded as standing-reserve. The concept of "human-resources" is a typical example of this situation (Heidegger, 1993: 323). Furthermore, in modern technology, the Greek conception of matter, that is, lying ready and lying before, turns out to be "presence at hand" and, thusly, becomes an invitation to the brutal abuse of nature. In this conception, "Nature" becomes a calculable phenomenon (i.e., growing things and other beings turn into raw material and/or objects of scientific research) and nothing can remain authentic. 
In light of the modern technological mode of production, both the authenticity of Dasein and that of producing is endangered because we experience ourselves properly as property of this outlook while, at the same time, we are deceived by subjectivism according to which we are the doers, masters, of all that is happening (Heidegger, I993: 329).

In reality, Gestell is a sending of Being; itself. With regards 'destining', history means the history of Being and Gestell is only the current name for the destining in the overall history of Being (I993: 329).

At this point, we begin to see that Heidegger's notion of freedom is opposed to the subjectivist understanding of freedom-'free will'. Whereas the theory of agency defines human freedom as the complete independence or indeterminacy of human beings in their decisive activity and; thus, in their will, Heidegger sees freedom both in the capability that human beings realize their "attachment" to Being-in the sense that Dasein becomes the open site, the clearing, wherein Being shows itselfand in that, only freedom "starts a revealing on its way," a free revealing (Heidegger, 1993: 330). Therefore, we are but slaves of Being unless we can establish a free relationship with it. Once more, in these sentences it is apparent that Heidegger's main concern is the essence of human being, human freedom and; hence, he constructs a peculiar sense of humanism. This version of humanism is far fairer to Being and entities but still it involves a certain amount of anthropocentrism.

Another important term is 'the mystery', but it should be understood together with 'freedom' and 'the danger': “...that which frees-the mystery-is concealed and always concealing itself. All revealing comes out of the free [Dasein,] goes into the free, and brings into the free" (Heidegger, I993: 330). The danger lies in humans' misunderstanding their position in the interplay of the concealment-unconcealment of Being; i.e., not seeing what they are already experiencing-the destining of revealing-because even in the event of unconcealment human beings are deceived in that they cannot see the authority of Being. Humans can remain free only through willingly accepting a partnership with Being; i.e., by being neither a slave of the destining nor pretending to be the Lord of it (Heidegger, I993: 329-332). Therefore, what is primarily endangered by Gestell, the ordering of everything (including human beings) as Bestand, is 
the "ek-sistence" of human being; i.e., the possibility that they essence themselves as Dasein (332). In the mode of enframing (Gestell), our possibility to see the danger as a danger is "blocked" (333; Heidegger, 1962: 27).

\section{Conclusion: The Saving Power}

Although it is not a subjectivism in the Kantian sense, Heidegger (I993)'s humanistic consideration is evident throughout his questioning of technology. It is true that he underlines the priority and authority of Being and argues that the danger is also a threat to Being itself because in the absence of a free being, Being can no more come shining-forth, and Truth cannot happen (333). In other words, Dasein provides the clearing for the completion of the aletheic movement, but the movement itself is prior to the human response to it. However, the endurance of human essence as a free being is, in some sense, dependent upon the continuity of the relation between human being and Being. I think, anthropocentrism reigns in the circularity of the argument from aletheia because we can still go one step further and ask why it would be a matter for Being to disclose itself in the clearing provided by Dasein. To ask differently, why are we supposed to accept Heidegger's ontological claim that it is physis itself who decided to divide itself into two different regional ontologies; i.e., 'the natural' and 'the artificial'?

When it comes to 'the saving power', Heidegger (1993) defines the phrase "to save" something, as bringing it back into its essence, into its proper appearing (333). Therefore, in questioning technology; i.e., realizing that the essence of modern technology is revealing everything as standing reserve-especially by looking carefully into the danger in itwe can see the saving power of which root is the danger itself (334). Nevertheless, it is not easy to see this fact, suddenly, in a glimpse. Only through careful consideration and thinking with a view to stand open to Truth, and by meditating on the essence of modern technology we can see the saving power growing in the danger. "... [Human being] may be the one who is needed and used for the safekeeping of the essence of truth. Thus, the rising of the saving power appears" (338). Therefore, only when we start regarding Gestell as a danger we may see the growth of the saving power in it. 
Furthermore, Heidegger states that our reflection upon technology must happen in a realm which is quite different from Gestell, that is, Art, as long as its eyes are open to the constellation of truth (Heidegger, I993: 340).

There was a time when it was not technology alone that bore the name tech$n e$. Once revealing that brings forth truth into the splendour of radiant appearance was also called techne...the poiesis of the fine arts was also called techne (Heidegger, I993: 339).

In the age of pre-Socratic philosophy, Art was not an activity of a privileged sect, and it was simply named as techne because it belonged within poiesis; i.e., bringing forth and making present (Heidegger, I993: 339). At that time, art was concerned with safekeeping of truth in the sense of aletheia and devoted itself to the aletheic movement, poiesis (339).

I think, Heidegger's interpretation of the Ancient Greek conception of Being is constructed in a way to centralize the notions of techne and art. All in all, techne belongs to the human realm and art, the highest form of techne, is constitutive of the human world. Nevertheless, in a world where it is so apparent that the destruction of nature is at its peak, dwelling so much and mainly on the possibility of authentic art; i.e., seeking for a salvation in this deed, is a hidden eulogy of the productive aspect of human being.

In this sense, I have regarded Heidegger's philosophy or, at least, this major work, as a questioning about technology concerning human being. A residue of anthropocentrism and a certain type of humanism have been discovered in Heidegger's thinking of Being. This is called a 'discovery' because it is Heidegger's own thinking which regards humans as an inseparable correlate of Being which is already lying before and lying ready for Dasein's response. With this regard, the overriding reason for claiming that there is a residue in Heidegger's philosophy is that, while rejecting a Platonic anthropocentrism or an enlightenment-humanism, he follows his own sense of humanism, and regards the deterioration of the essence of Dasein as the worst thing that can happen to Being. This is an ipso facto prioritization of human being whose essence must remain free vis-à-vis other beings. 


\section{References}

Brogan, W. A. (2007). The Intractable Interrelationship of Physis and Techne in Heidegger's Philosophy. Heidegger and the Greeks. (Eds. D. A. Hyland \& J. P. Manoussakis). Bloomington: Indiana University Press, 43-56.

Cicero, M. T. (I886). Book V. Virtue Sufficient for Happiness. Tusculan Disputations. (Trans. A. P. Peabody). Boston: Little, Brown and Company, 25I-322.

Heidegger, M. (1962). Die Technik und die Kehre. Stuttgart: Verlag Günther Neske, $5-36$.

Heidegger, M. (1993). The 2uestion Concerning Technology. (Trans. W. Lovitt). Basic Writings. New York: Harper Collins, 3II-4I.

Heidegger, M. (1996). Being and Time. (Trans. J. Stambaugh). Albany: State University of New York Press, 83-94.

Heidegger, M. (1998). On the Essence and the Concept of $\Phi v \sigma ı \varsigma$ in Aristotle's Physics B, I. Pathmarks. (Ed. W. McNeil). The UK: Cambridge University Press, I83-230.

Ruin, H. (2010). Ge-stell: Enframing as the Essence of technology. Martin Heidegger Key Concepts. (Ed. B. W. Davis). UK: Acumen Publishing, I83-93.

Zimmerman, M. E. (1990). Heidegger's Confrontation with Modernity Technology, Politics, and Art. The USA: Indiana University Press.

Öz: Heidegger, Tekniğe İliskin Sorgulama metninde, Dasein'in insan özüyle ve diğer varlıkların özleriyle ilișkisini belirleyen șeyin aslında Varlığın kendi kendine biçtiği kader olduğunu, ancak fail neden olma yanılgısı içindeki modern zihnin bu durumdan haberdar olmadığını iddia eder. Böylesi bir körlük, yalnızca insanın özsel özgürlüğ̈nü tehdit etmekle kalmayıp, doğal varlıkları da otantikliklerini yitirme riskiyle karșı karșıya getirir; çünkü modern üretim biçimi doğayı insani edimler için her an hizmetimize amade, edilgen bir kaynak biçimde algılar. Batı metafiziğin temelinde yatan bu bakış açısına eleștirel yaklașmasına karșın, Heidegger'in kendi felsefesinde insan-merkezcilik sorununu așıp așamadığı ise bu makalede yürütülecek olan tartıșmanın konusudur.

Anahtar Kelimeler: Heidegger, insan-merkezcilik, doğa, Dasein, teknoloji, teknik, sanat. 